\title{
TANULMÁNYI EREDMÉNYESSÉG A TEHETSÉG, AZ EGÉSZSÉG ÉS A SZOCIÁLIS KAPCSOLATOK TÜKRÉBEN EGYETEMISTÁK KÖRÉBEN
}

\author{
Szerzők: \\ Józsa Bianka \\ Debreceni Egyetem (Magyarország) \\ Kárándi Gergő Mihály \\ Debreceni Egyetem (Magyarország) \\ Motel Petra Blanka \\ Debreceni Egyetem (Magyarország) \\ Visnyei Lili \\ Debreceni Egyetem (Magyarország) \\ Első szerző e-mail címe: \\ biankajozsa@gmail.com
}

\author{
Lektorok: \\ Kovács Karolina Eszter $(\mathrm{PhD})$ \\ Debreceni Egyetem (Magyarország) \\ Ceglédi Tímea (PhD) \\ Debreceni Egyetem (Magyarország)
}

Józsa Bianka, Kárándi Gergő Mihály, Motel Petra Blanka, Visnyei Lili (2021). Tanulmányi eredményesség a tehetség, az egészség és a szociális kapcsolatok tükrében egyetemisták körében. Különleges Bánásmód, 7. (2).

43-56. DOI 10.18458/KB.2021.2.43

\begin{abstract}
Absztrakt
Háttér és cél: A tanulmányi eredményességet számos intra- és interperszonális faktor határozza meg. A tehetség olyan személyen belüli tényező, amelynek szerepe a tanulmányi előmenetelben kétségkívüli (Dávid és tsai, 2014a; Mező, 2008; Ceglédi, 2008). Az egészségtudatosság szintén személyen belüli tényező. A rendszeres fizikai aktivitás és a pozitív énkép, ezen belül a testképpel összefüggő önértékelés pozitív hatást fejt ki a tanulmányi teljesítményre (Kovács, 2020). Ezentúl az interperszonális és környezeti tényezők szerepét is szükséges hangsúlyozni (Szemerszki, 2015; Ceglédi, 2012). Ugyanakkor e tényezők deficitjei (amelyek közül igen súlyos például a kirekesztés) ellentétes hatással bírnak. Kutatásunkban az önértékelt tehetségpreferenciák, az önmagunkkal való elégedettség, a rendszeres fizikai aktivitás, valamint a kirekesztettséggel kapcsolatos megküzdés szerepét vizsgáltuk a Debreceni Egyetem hallgatói körében (N=159). Eredmények: A lineáris regresszióanalízis eredményei alapján a kirekesztés maga negatív hatással bír a tanulmányi eredményességre, azonban pozitív hatást mutat az én-elégedettség, valamint a kirekesztéssel való megküzdés. Eredményeink felhívják a figyelmet a szociális kapcsolatok és a kirekesztés elleni prevenció fontosságára, hiszen a társas kirekesztés hosszútávon az önértékelésre és a felsőfokú tanulmányi eredményességre is kihat, és annál erősebb, minél korábbi színtéren jelenik meg.
\end{abstract}

Kulcsszavak: megküzdés, elégedettség, sport, tehetség, tanulmányi eredményesség

Diszciplina: pedagógia, pszichológia 


\begin{abstract}
ACADEMIC ACHIEVEMENT OF HIGHER EDUCATIONAL STUDENTS IN THE LIGHT OF TALENT, HEALTH AND SOCIAL RELATIONSHIPS

Background and aim: Academic achievement is determined by several intra- and interpersonal factors. Talent is an internal factor whose role in academic progress is unquestionable (Dávid et al., 2014a; Mezó, 2008; Ceglédi, 2008). Health awareness is also an internal factor that has a significant effect on academic achievement, considering the positive effect of regular physical activity and positive self-image, and body image within the latter (Kovács, 2020). Also, interpersonal and environmental factors need to be emphasized, as adequate social support can significantly improve performance and can also play a crucial role in disadvantage compensation (Szemerszki, 2015; Ceglédi 2012). However, deficits of these factors (of which exclusion is very severe, for example) have the opposite effect. In our research, we examined the role of self-assessed talent preferences, self-satisfaction, regular physical activity, and coping with exclusion among the students of the University of Debrecen $(\mathrm{N}=159)$. Results: Based on the results of the linear regression analysis, exclusion itself has a negative effect on academic achievement, but selfsatisfaction and coping with exclusion show a positive effect. Our results draw attention to the importance of social relationships and prevention of exclusion, as it is clear that social exclusion has a long-term impact on self-esteem and higher academic achievement, and is stronger the earlier it appears.
\end{abstract}

Keywords: coping, self-acceptance, sport, talent, academic achievement

Disciplines: pedagogy, psychology

\section{Bevezetés}

A tanulmányban együtt kutatunk két olyan témakört, amelyeket korábban jellemzően különkülön vizsgáltak. A tehetség (és tehetséggondozás), és az egészség egyes dimenzióinak vizsgálata számos kutatás fókuszában áll napjainkban is (lásd. Dávid és tsai, 2014a; Harmatiné-Olajos és Pataky, 2014; Rongen és tsai, 2018; Groves, 2011; Adelson, 2007). A két terület közötti összefüggések feltárása azonban kevésbé kutatott terület, noha nem kérdéses, hogy a tehetség mint tanulmányi eredményességi aspektus, és az egészség mint nemtanulmányi eredményességi mutató között lényegi kapcsolat állhat fenn, melynek manifesztációját természetesen az intra- és interperszonális, és a környezeti-társadalmi hatások is befolyásolhatják. Ebben a megközelítésben a sport, a megküzdés és az önértékelés/én-elégedettség egyaránt nemtanulmányi eredményességként fogható fel, melyek közül a sport inkább objektív, a megküzdés és énelégedettség pedig inkább szubjektív egészségtudatossági mutatóként tartható számon (Kovács, 2020). Kutatásunk célja e témakörök, s a közöttük fennálló kapcsolatok vizsgálata.

\section{Gondolatok a tehetségröl}

$\mathrm{Az}$ egyes tehetségkoncepciók eltérő területekre helyezik a fókuszt. Bagdy és tsai (2014) olyan kérdésekre keresték a választ, hogy lehetséges-e, illetve szükséges-e a kiemelkedően tehetséges fiatalok egyéni szükségleteire és személyes problémáira illeszkedő személyiségfejlesztés, mentális és pszichológiai támogatás. A kutatás elsősorban a jövőben megmutatkozó tehetségekre koncentrál, akiknél már bebizonyosodott, hogy kreatívak, kellóen motiváltak és kortársaikhoz viszonyítva kiemelkedőbbek. Harmatiné és tsai (2014) a 
differenciálás alapvetőségét hangsúlyozzák tehetséggondozásban, illetve tárgyalják a módszertani lehetőségeket is a tehetségfejlesztés során. Ceglédi (2018, 2020) elsősorban a hátrányos helyzetú tehetségekkel foglalkozik, véleménye szerint az elkallódott tehetség az egyik tünete a társadalmi egyenlótlenségeknek. Emellett felhívja a figyelmet arra, hogy fontos, hogy a gondozatlan tehetségek is lehetőséget kapjanak szárnyaik próbálgatására, határaik feszegetésére.

A tanulmányi eredményességet intra- és interperszonális faktorok határozzák meg. A tehetség olyan személyen belüli tényező, amelynek a tanulmányi előmenetelben megmutatkozó szerepe kétségkívüli, viszont a tehetség kibontakozására ható tényezôk megítélésében jelentős eltérések vannak (Dávid és tsai, 2014a; Mező 2008; Ceglédi, 2008). Emellett a tehetség kibontakozásában az interperszonális és környezeti tényezôk szerepét is szükséges hangsúlyozni, hiszen a megfelelő társas támasz, olyan hozzáadott értéket képvisel, amely jelentősen képes javítani az eredményességet, illetve a hátránykompenzációban is jelentős szerepet kaphat (Szemerszki, 2015; Ceglédi, 2012).

Sinkó (2009) és Fekete (2019) kiemelik a pozitív ráhatások fontosságát, a motiváció megteremtését és a szülói feladatokat, hiszen nem csak a pedagógusokra és szakemberre szükséges hagyatni, ha tehetséges gyermek felfedezéséről van szó (Bacskai, 2020). A környezeti faktorok között fontos szerepet kaphatnak a különböző tehetséggondozó és mentorprogramok is (Dávid és tsai, 2014b; Godó és tsai., 2020; Hafičová és tsai., 2020).

A tanulmányi eredményesség, a tehetség kibontakozása és egészségtudatosság közötti kapcsolat jelentős, tekintve a rendszeres fizikai aktivitás és a pozitív énkép, ezen belül a testképpel összefüggő önértékelés, tanulmányi teljesítményre kifejtett pozitív hatását (Kovács, 2020; Kovács és Nagy, 2015). Feltételezhető, hogy ha egy tanuló egészségmagatartása pozitív, akkor a tehetség elkallódására is kisebb az esély.

\section{Egészségmagatartás}

Az egészséggel foglalkozó témakörök érintik a táplálkozást, és az ezzel összefüggő problémákat is, amelynek vizsgálatára egyre nagyobb hangsúly helyeződik (Szumska, 2004). Az evészavarokat vizsgáló kutatások két nagyon súlyos betegséget említenek leggyakrabban - az anorexiát és a bulimiát (Dukay-Szabó és Túry, 2008; Túry, 2002), jóllehet az étkezési zavarok spektruma bővül. Kialakulásukhoz számos tényezô hozzájárul: szociokulturális, családi jellegzetességek, egyéni pszichés és biológiai prediszpozíciók. Alapvető tendencia, hogy az étkezési zavarok kialakulása leginkább a nők és fiatal lányok esetében jellemző, továbbá a betegségek lefolyása általában évekig elhúzódhat. A táplálkozászavarok hosszú távon számos testi szövődményt vonnak magukkal, ezért az életminőséget jelentős mértékben rontja (Túry, 2002), amely negatív hatással van mind a tanulmányi eredményesség, mind a tehetség kibontakozására.

$\mathrm{Az}$ egészségmagatartás szoros kapcsolatban áll az önértékeléssel, valamint az azokra vonatkozó érzékelésekkel, amelyek az egészség megőrzéséhez hozzátartozó habitusok és attitűdök kiválasztásának és állandóvá válásának befolyásoló tényezői. Az alacsony önértékelés azonban olyan negatív hatásokkal jár, mint a táplálkozási zavarok és az alkalmazkodási nehézségek (Csibi és Csibi, 2013). Fontos tehát, hogy a fiatalok esetében időben felfedezzük a testkép és táplálkozási zavarok jelenlétét, hogy elkerülhessük az ebből adódó életviteli, önértékelési és tanulmányi eredményességbeli nehézségeket, tehetségük elkallódását (Lajos, 2005).

$\mathrm{Az}$ egészségtudatosság és a tanulmányi eredményesség között is összefüggés mutatható ki. Az egészségtudatos magatartás jellemzően magasabb tanulmányi eredményességgel, míg az egészségkockázati magatartás a tanulmányi eredményesség alacsonyabb fokával (pl. rosszabb osztályzatok, magasabb lemorzsolódás) jár együtt (Kovács, 2020). 
Az egészségmagatartás a tehetség kibontakozásával is összefüggésben áll. A jó tanulmányi eredmény elérése érdekében az iskolai környezet támogatja a versenyt, az egyéni teljesítmény nyilvános ellenőrzését és minősítését. Folyamatosan jelen van a teljesítmény, a kompetencia és a tökéletesség elvárása, és ezek egyre jobb tanulmányi és sporteredmény elérésére ösztönzik a diákokat. Az ez által okozott stressz azonban gyakran negatív irányba mozdítja a tanuló egészségét, hiszen növeli a szorongás és stressz szintjét, amely optimális mértékben pozitívan hat a teljesítményre, tartós és folyamatos emelkedett szintje azonban nemcsak a tanulmányi eredményességet rombolja, hanem az egészséget magát is (Dávid és tsai, 2014b). Továbbá a versenyeztetés hatására megerôsödik a másokkal való összehasonlítás lehetôsége, amely nem korlátozódik a tanulással kapcsolatos területekre. Több lány számolt be arról, hogy a kortársaik elismerését akarták kivívni azzal, hogy vékonyak lesznek és intenzív súlycsökkentésbe fogtak. Különböző negatív élményeikrôl számoltak be a teljesítménnyel, az egyének és évfolyamok közötti versennyel, a státusszal, zaklatásokkal, a kortárscsoport kirekesztésével kapcsolatban. A lányok elbeszéléseiből kitűnt, hogy az iskolai kultúra és a családi élet nyomást helyezett a serdülőkre a tökéletesség és a teljesítmény irányába. Gyakran olyan dolgot vártak el tôlük, amit lehetetlen volt elérni. Ez a tehetetlenség érzését idézte elő bennük, elidegenedtek a testüktől, és a testük feletti rögeszmés kontroll az életük alapeleme lett (Evans, Rich és Holroyd, 2004; Ludányi és Szabó, 2017).

\section{Sport}

Az Európai Sport Charta (1997) meghatározása szerint "A sport minden olyan fizikai tevékenység, amelynek célja esetenként vagy szervezett formában a fizikai és szellemi erőnlét kifejezése vagy fejlesztése, társadalmi kapcsolatok teremtése vagy különböző szintű versenyeken eredmények elérése".
Az edzés olyan fizikai aktivitási kategória, amely tervezett és strukturált, ismétlődő, céltudatos testmozgások elvégzését tartalmazza, amely egy vagy több fizikai fitneszkomponens (például aerob fitnesz, izomerō, izom-állóképesség, ízületi mozgékonyság és testösszetétel) szintjének megtartását vagy fejlesztését célozza (Csányi, 2010). Szabadidős fizikai aktivitásnak nevezhető az a fajta testedzés, sport, rekreáció vagy olyan hobbitevékenység, amely nincs kapcsolatban a kötelező munkahelyi, közlekedéses vagy háztartáshoz kapcsolódó fizikai aktivitással (Csányi, 2010).

Napjainkban a fiatalok körében, ha a szabadidő eltöltéséről van szó, egyre inkább háttérbe kerülnek a különböző testmozgással járó tevékenységek. Ugyan a fizikai aktivitás és az egészség közötti kapcsolat vitathatatlan, helyette egyre gyakrabban a fizikai aktivitással nem járó szabadidőtöltési formák válnak jellemzővé (például internetezés, videójáték stb.). Azonban bizonyítható, hogy a sport kiemelkedő hatással lehet a fiatalok személyiségére, taníthat kitartásra, és pozitív hatással lehet mentális egészségükre, önbizalmuk növelésére (Kovács és Nagy, 2017a), egy általános elégedettségérzés irányába segíthet (Kovács és Nagy, 2017b), valamint a társas kapcsolatok fejlesztésén keresztül protektív tényezőként szolgál a kirekesztettség ellen is (Kovács. 2015; Kovács, 2020). Mindazonáltal a tehetség kibontakozására is pozitív hatással lehet, valamint a szociális készségek fejlesztésén keresztül a sportkapcsolatok mellett a kortárskapcsolatok erôsítésében és kiteljesedésében is segít, ezáltal védve a kirekesztéstől (Kovács, 2020).

Az Eurobarométer 2017-es adatai alapján (European Commission, 2018) az európai lakosság közel fele nem sportol, és nem is végez semmilyen testmozgást, és ez a csoport jellemzően növekvő tendenciát mutat. Míg a megkérdezettek 40\%-a legalább egy héten egyszer végez valamilyen fizikai aktivitással járó edzést vagy sportot, mindössze 7\%-uk sportol rendszeresen (heti legalább öt alkalommal). Azoknak az aránya, akik bevallásuk sze- 
rint semmilyen testmozgást nem végeznek, 2013 óta 42\%-ról 46\%-ra nőtt. A kutatásban megfigyelhető az is, hogy a férfiak többet sportolnak és/vagy vesznek részt fizikai aktivitással járó tevékenységekben, mint a nők, ez különösen a 15-24 év közötti korcsoportra jellemző, és az is kimutatható, hogy a fizikai aktivitás mértéke a korral láthatóan csökken. Ennek egyértelmú oka lehet, hogy az életszakaszaink előrehaladásával a szabadidőnk csökken és ezzel szemben a kötelességeink és felelősségeink egyre csak nőnek, s ezek természetesen egyre csökkenő motivációt is eredményezhetnek a fizikai jóllétünk fenntartására.

A fent említett kutatásban különböző a testmozgásra motiváló tényezőként megjelenik az egészség fenntartása, megőrzése vagy javítása (54\%), a kondíció, erőnlét fejlesztése (47\%), relaxációs okok (38\%), a szórakozás $(30 \%)$, és a fizikai teljesítmény növelése (28\%). Ezekkel szemben hátráltató tényezôként túlnyomórészt az idő hiányát jelölték meg.

\section{Kirekesztés és megküzdés}

Ercsei és Nikitscher (2012) a kérdőíves kutatásukban, a különböző típusú atrocitások megjelenését, észlelését, valamint a helyzet megoldását vizsgálták, utóbbit a diákok és a tanárok között. Megállapították, hogy a kiközösítés elszenvedôi leginkább olyan diákok voltak, akik, valamilyen társadalmi vagy testi szempontból hátránnyal indultak a többiekhez képest, gyengébbnek bizonyultak és/vagy maguk megóvására képtelenek voltak. Később Fehér (2019) is hasonló megállapításra jutott: azért válik valaki áldozattá, mert más: például másként néz ki, gyengeség, esetleg betegség látható rajta. Továbbá azt is megállapította, hogy a kirekesztés nem feltétlenül azért jön létre, mert a két személy között konfliktus van, hanem mert a kirekesztőnek volt szüksége az érzelmei megerősítése miatt arra, hogy egy nála gyengébbet alárendeljen. Megfigyelhető, hogy az osztályokban a tanulók csoportokat alkotnak és a gimnáziumokban mindig van egy olyan csoport, amely az egyetemi évekre próbál felkészülni és keményen tanul. Az erőfeszítéseik azonban azon a csoporton belül maradnak, ahová tartoznak és az egyéb társas tevékenységekből kimaradnak így például a sportból is (Coleman, 1996). Hadházy (2016) hátrányos helyzetú tanulók között is igazolta, hogy az áldozatok leginkább olyan személyek, akik valamiben mások, mint az elkövetô, például gyengébbek, védtelenebbek, szemüvegesek vagy kisebb növésúek.

A kiközösítéssel való megküzdéssel foglalkozó vizsgálatában Fehér (2019) megfogalmazta, hogy a kirekesztettek számára segítséget jelent a kommunikációfejlesztés és az érzékenység átdolgozása, továbbá szükségük van odafigyelésre, nyitottságra, empátiára. Ha valaki úgy érzi, hogy egy csoporttól kap elutasítást, akkor fontos a közös élményszerzés és a „mi-tudat” erősítése. Egy kiközösített személynek fontos, az „én”-jének újradefiniálása is a pozitív visszajelzéseken keresztül.

A tehetségek általában könnyebben küzdenek meg az őket ért veszteségekkel, mert képesek a pozitív oldalát látni mindennek és a kudarcokat felhasználva tovább fejlődni (Ceglédi, 2012). Vannak viszont az alulteljesítő tehetségek, akik nem tudják feldolgozni a vesztést önfejlesztő módon, így nekik a megküzdés is nehezebben mehet (Fülöp, 2014). Ha olyan mértékủ az elutasítás, hogy már nem hozható helyre, akkor célszerúbb új kapcsolatokat kialakítani és más kötődési pontokat keresni, valamint szakembert (például iskolapszichológust) is bevonni. Emellett fontos a kirekesztett személy családjával való foglalkozás is, hiszen az édesanya érzelmi bevonódása, az édesapának együttérző reakciói hasznosak. Ercsei és Nikitscher (2012) szerint a kirekesztés esetén gyakran egy másik diák próbálja visszafogni az elkövetőt vagy értesíti a tanárt. A pedagógus nehéz helyzetbe kerül, tettenérés hiányában nehezen tudja beazonosítani a probléma mértékét, az áldozatok pedig félnek a 
megtorlástól. Hadházy (2016) is alátámasztja azt tanulmányában, hogy az áldozatok gyakran annyira szégyellik helyzetüket, hogy nem kérnek segítséget.

A kirekesztés hátterében az átlagostól való eltérés állhat, így előfordulhat, hogy a tehetséges tanulók is ki lehetnek téve a kirekesztés és bántalmazás különböző formáinak. Ebben az esetben a tanuló pozitív énképe, adaptív copingmechanizmusai mint intraperszonális faktorok szerepe kiemelkedő, ugyanakkor a környezet (otthon a szülók, iskolai környezetben pedig a pedagógusok) részvétele és támogatása kiemelendő (Pataky, 2014; Oláh, 2005). Ez a folyamat azonban, ha megoldatlan marad, a tehetség kibontakozását akadályozhatja.

\section{Módszer}

A kutatás fókuszában a tehetség, elégedettség, sport és kirekesztéssel való megküzdés, valamint ezek összefüggései állnak. A Background Effects of Students - Today (BEST 2020) nevet viselő, egyetemistákra irányuló vizsgálatunkban kitértünk arra, hogy a szubjektíve tehetséges tanulókra vajon nagyobb mértékben jellemző-e a kirekesztés, vagy a rendszeresen sportoló hallgatók eredményesebbek a kirekesztéssel való megküzdés tekintetében. Megvizsgáltuk, hogy az önmagukkal való elégedettség nagyobb arányban jelenik-e meg a tehetséges, valamint a sportoló tanulók körében, valamint górcső alá helyeztük e négy tényezô tanulmányi eredményességre kifejtett hatását is.

\section{Minta}

A minta nem reprezentatív semmilyen elózetes ismérv alapján. Kutatásunk eredményeinek általánosíthatósága ezáltal korlátozott. A célcsoportnak megfelelően a válaszadók $(\mathrm{N}=200)$ többsége egyetemi hallgatókból állt, a nem egyetemi hallgatókat leválogattuk a mintából (így az elemzett mintanagyság $\mathrm{N}=157)$. A válaszadók 89,7 \%-a nő, 10,3\%-a férfi volt. A kitöltők átlagéletkora 22,87 év $(\mathrm{sd}=6,59)$.

Kutatásunkban az önértékelt tehetségpreferenciák, az önértékelés, a rendszeres fizikai aktivitás, valamint a kirekesztettséggel kapcsolatos megküzdés szerepét vizsgáltuk meg. Célunk a testképpel kapcsolatos attitűdök, az általános és kirekesztettséggel kapcsolatos megküzdés, valamint a sportolási szokások és a tehetséggel kapcsolatos megítélések feltérképezése. A kutatás hipotézisei:

- A tehetséges tanulókat magasabb arányban éri kirekesztés, és a kirekesztéssel való megküzdésük magasabb, mint a nem tehetséges tanulóknak.

- A sportoló hallgatókat alacsonyabb arányban éri kirekesztés, és ha ez mégis megtörténik, sikeresebben küzdenek meg vele.

- A tehetséges és a sportoló hallgatók elégedettebbek önmagukkal.

- A tanulmányi eredményességre a kirekesztés ténye negatívan hat, míg a rendszeres sporttevékenység, a hallgató önmagával való elégedettsége, valamint a kirekesztéssel való megküzdés pozitívan hat.

\section{Eszközök}

A kutatás online kérdőívre támaszkodott. A kérdőívben a különböző faktorokat vizsgáltuk:

- szociodemográfiai kérdések

- tehetségre irányuló kérdések, tehetségpreferenciák

- sportolási szokásokra irányuló kérdések

- táplálkozási szokásokra vonatkozó kérdések

- önértékelésre vonatkozó kérdések

- kirekesztettséggel való megküzdésre vonatkozó kérdések

Ezek a változók adták a kutatás függő változóit. A hatásvizsgálat során a függő változót a tanulmányi eredményesség adta, a kirekesztéssel és megküzdéssel, sportolással, valamint elégedettséggel kapcsolatos változók pedig független változóként szerepeltek. 


\section{Eljárás}

A kérdőívet online készítettük el google kérdőív formájában, amely különböző social media felületeken került megosztásra. A statisztikai elemzéshez az adatokat Excel táblázatban rögzítettük az elemzéshez SPSS 22.0 for Windows statisztikai szoftvert alkalmaztunk. Az eloszlásbeli különbségek feltárásához khi-négyzet próbát alkalmaztunk, a csoportok közötti összevetéséhez (folytonos változók esetén) az adatok nem normális eloszlására való tekintettel (Kolmogorov-Smirov próba, $\mathrm{p}<0,05)$ Mann-Whitney próbát alkalmaztunk, a hatásvizsgálathoz pedig lineáris regresszióanalízis alkalmazására került sor.

\section{Eredmények}

\section{Kirekesztés és coping - helyzetkép}

A válaszadók több, mint fele (52\%) esetében nem történt kirekesztés egyik oktatási színtéren sem. A színterek közül a legnagyobb arányban az általános iskola jelent meg (25\%). A kitöltők többsége, 56\%-a jelölte azt, hogy néhány emberre számít-hatott. 25\%-uk számíthatott sok osztálytársára, 11,5\%-uk csak egy barátról számolt be, 7,5\%uk pedig azt jelölte, hogy senkire sem számíthattak. A válaszadók $62 \%$-ának nem volt szüksége segítségre a kirekesztés leküzdéséhez. 24\%-uk nem kért segítséget, míg 14\%-uk külső segítségért fordult. Az 1. ábra szemlélteti a személyeket, akiktől az érintett hallgatók segítséget kértek.

1. ábra: Kitöl kértél segitséget a kirekesztés lekürzdéséhez? (\%) (Forrás: BEST 2020)

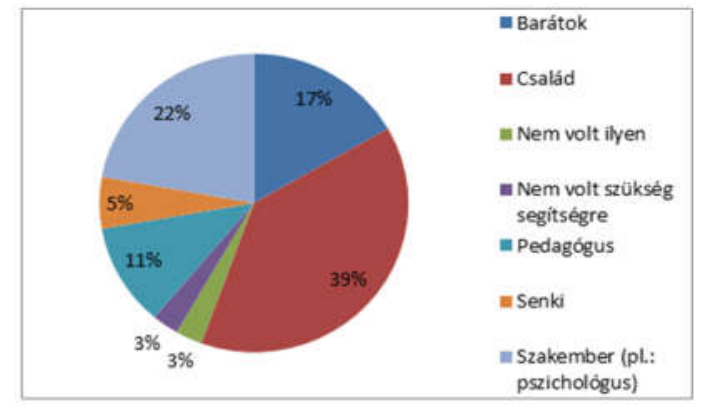

A válaszadók jelentős része a családjához (39\%) vagy barátaihoz (17\%) fordult, $22 \%$-uk professzionális segítséget igényelt valamely segítő szakembertől (pszichológus), 11\%-uk pedig valamely pedagógustól. A kirekesztésben érintett válaszadók 76\%-ában a sikeres megküzdés ellenére is nyomot hagyott a kirekesztés.

\section{Tehetség és kirekesztés}

Megvizsgáltuk az önértékelt tehetségpreferenciákat. Eredményeink alapján a középiskolai tanulmányok tekintetében a leginkább kedvelt tárgynak az irodalmat (16\%), a történelmet $(14,7 \%)$ és a biológiát (12,8\%) jelölték. A válaszadók 71\%-a állította, hogy kedvenc tantárgyában ő volt az egyik legkiemelkedőbb tanuló az osztályában. 86,5\%-uk vett is részt versenyen a kedvenc tantárgyukban. A kitöltők 54\%-a nem vett részt tehetséggondozó foglalkozáson az iskoláján belül. 6\%-uk már óvodában is részt vett tehetségfejlesztésen, 22,5\%uk általános iskolában, 8\%-uk pedig vett részt tehetséggondozó programon. A kitöltók 0,5\%-a jelentette, hogy óvodában és általános iskolában vett részt ilyen programon, $11 \%$-ukra ez általános és középiskolában volt jellemző, s mindössze 1\%uk vett részt már óvodás korától kezdve egészen a középiskolás évekig tehetségfejlesztő foglalkozáson.

A kitöltők 30,5\%-a vett részt mûvészeti foglalkozásokon (pl. rajzszakkör, tánc egyesületi tagság, énekkar), 17\%-uk sportfoglalkozásokon, 28\%-uk mindkettő típusú foglalkozáson, míg 24,5\%-uk nem vett részt egyik típusú tehetségfejlesztő foglalkozáson sem. A kitöltők 85\%-a válaszolta azt, hogy abban a tantárgyban, amelyben tehetségesnek bizonyult, osztálytársai rendszeresen kértek tőle segítséget.

A tehetséget - az önértékelés mellett - a versenyszerepléssel is azonosíthatjuk. Ez alapján a versenyszereplők 49,1\%-a volt kirekesztett pozícióban, míg a versenyeken nem szereplók esetében ez az arány 
40,7\% volt. Az eloszlásbeli különbség a khi-négyzet próba eredménye alapján nem szignifikáns $(p=0,407)$, tehát akiket versenyszereplésük alapján tehetségesek közé soroltunk, sem védettnek, sem veszélyeztetettnek tekinthetők a kirekesztés kapcsán.

Megnéztük azt is, hogy a tehetségesek milyen arányban tudtak megküzdeni a kirekesztéssel. A tehetségesek 77,6\%-ában hagyott nyomot a kirekesztés a sikeres megküzdés ellenére, míg a nem tehetségesek esetében ez az arány $66,7 \%$ volt. A különbség azonban ebben az esetben sem szignifikáns $(\mathrm{p}=0,402)$. Első hipotézisünk tehát nem igazolódott be.

\section{Sport és kirekesztés}

A hallgatók 25,3\%-a naponta, 42,2\%-uk hetente, 14,8\%-uk pedig ritkábban sportol, többségük (95\%) hobbiszinten, 2,4\%-uk versenyszinten megyei vagy városi bajnokságokon, míg csupán 1,8\%-uk sportol versenyszerúen országos, nemzetközi, NB1, NB2 vagy ennek megfelelő szinten. A nők 18,7\%-a sportol naponta, 44,8\%-uk hetente, 13,4\%-uk havonta, 23,1\%-u pedig ennél is ritkábban. A férfiak esetében más tendenciák mutatkoznak: 42,4\%-uk sportol napi, 33,3\%-uk heti, 12,1\%-uk havi szinten, 12,1\%-uk pedig ennél ritkábban, az eloszlásbeli különbségek tehát szembetúnőek és szignifikánsak a két nem között $(\mathrm{p}=0,032)$. A versenyszerúen sportoló hallgatók 28,6\%-a jelentette azt, hogy sportolási kötelezettségeik jelentősen kihatnak tanulmányi eredményességükre. A hallgatók több mint fele (51,5\%-uk) válaszolta azt, hogy szüleik akkor is támogatnák a (verseny)sportban, ha ez a tanulmányi eredményeinek visszaesésével járna. Egészségtudatosság szempontjából pedig a hallgatók túlnyomó többsége, 94,6\%-a egyetért azzal a kijelentéssel, hogy az egészséges életmódhoz elengedhetetlen valamilyen testmozgás rendszeres végzése.

Feltételeztük, hogy a sportoló személyekre kevés- bé jellemző a kirekesztés. Az eredmények alapján a sportoló (naponta vagy legalább hetente történő sporttevékenység) személyek $51,8 \%$-a volt az oktatás valamely színterén kirekesztve, a nem sportoló (havi szinten vagy ritkábban végzett sporttevékenység) hallgatóknak pedig 52,6\%-a számolt be kirekesztésrôl. A különbség a khinégyzet próba eredménye alapján nem szignifikáns $(\mathrm{p}=0,921)$. A sportoló személyek 72,7\%-ában hagyott nyomot a kirekesztés ténye, míg ez az arány a nem sportolók esetében ennél magasabb, 78,9\%, ugyanakkor az eloszlásbeli különbség nem szignifikáns ( $p=0,501)$. Második hipotézisünknek tehát egyik állítása sem igazolódott be: a sportolók ugyanolyan arányban áldozatai a kirekesztésnek, és ugyanolyan arányban küzdenek meg vele, mint nem sportoló társaik.

\section{Táplálkozási szokások, önértékelés}

Önértékelés tekintetében a válaszadók 50,9\%-a meg van elégedve önmagával. Az egészségtudatosság kérdéskörét tekintve a válaszadók 61,1\%-a jelölte azt, hogy rendszeresen reggelizik, 80,2\%-uk tartja be a napi legalább háromszori étkezést, ugyanakkor 68,1\%-uk rendszeresen jár gyorsétterembe. 68,3\%-uknál előfordult már, hogy éhes volt, de inkább nem evett, 12\%-uk diéta, 7\%-uk testkép- és táplálkozászavarok okán. Valamint a kitöltők több, mint fele (54,5\%-uk) számolt be arról, hogy vannak olyan napjai, amikor teljesen étvágytalan, máskor pedig "habzsol". 62,3\%-uk kifejezetten gyakran nassol, 38,9\%-uk szokott bűntudatot érezni, ha úgy gondolja, túl sokat evett. 52,1\%-ukkal már előfordult az, hogy idegesség/stressz miatt sokat evett, 70,7\%-uknál pedig az, hogy az idegesség/stressz miatt étvágytalan volt.

Harmadik hipotézisünkben feltételeztük, hogy a tehetséges tanulók körében magasabb azok aránya, akik elégedettek önmagukkal.

Az eredmények alapján a tehetséges tanulók 51\%-a elégedett önmagával, míg a nem 
tehetségesek esetében ez az arány 50\%. A különbség tehát nem jelentős a két csoport között $(\mathrm{p}=0,932)$. A sportoló hallgatók esetében elmondható, hogy 53,6\%-uk elégedett önmagával, míg a nem sportoló társaik 45,6\%-a vallotta azt, hogy elégedett magával. A különbség azonban ebben az esetben sem szignifikáns $(\mathrm{p}=0,325)$. Hipotézisünk tehát nem igazolódott be.

\section{Tanulmányi eredményesség a változók tükrében}

Végül lineáris regresszióanalízissel megvizsgáltuk a tanulmányi eredményességre ható faktorokat. Ehhez egy kétlépcsős modellben néztük meg a különböző szociodemográfiai és pszichológiai faktorok hatását (1.táblázat).

1. táblázat: A tanulmányi eredményességre bató faktorok (Forrás: BEST 2020, N=159)

\begin{tabular}{l|r|r} 
& \multicolumn{1}{c}{ 1. modell } & 2. modell \\
\hline Nem &,- 193 &, 014 \\
Anya iskolázottsága &, 025 &,- 159 \\
Apa iskolázottsága &,- 050 &,- 029 \\
Településtípus &,- 008 &,- 075 \\
Gyermekkori olvasás &,- 056 &, 023 \\
Válás &,- 143 &, 037 \\
Jelenlegi munkavégzés &, 248 &, $394^{*}$ \\
Kirekesztés ténye & &, $658^{*}$ \\
Kirekesztés-coping & &, $680^{*}$ \\
Elégedettség önmagával & &, $448^{*}$ \\
Sportolás & &, 363
\end{tabular}

Első modellünkbe a nem, az anya és apa iskolai végzettsége, a településtípus, a gyermekkori olvasás, a válás, valamint a jelenlegi munkavégzés bevonására került sor, míg második modellünkbe a kirekesztés tényének, a kirekesztéssel való megküzdésének, a személy önmagával való elégedettségének, valamint a rendszeres sporttevékenységnek változóit vontuk be.

A lineáris regresszióanalízis eredményei alapján a demográfiai háttérváltozók hatása nem jelentős, ugyanakkor a pszichológiai faktorok hatása szignifikáns. Bár a lányok eredményessége jobbnak mutatkozott, valamint a magasabb iskolai végzettségú szülők gyermekeinek tanulmányi eredményessége is jobbnak bizonyult, ezek a különbségek nem jelentősek a Mann-Whitney próbák eredményei alapján (nem: $\mathrm{p}=0,947$; anya iskolai végzettsége: $\mathrm{p}=0,364$; apa iskolai végzettsége: $\mathrm{p}=0,712$ ).

Ehhez hasonlóan a településtípus hatása sem jelentős, bár a nagyobb településeken (fóváros, megyeszékhely) élő tanulók enyhén jobb tanulmányi eredményességgel jellemezhetőek, mint kisebb településen élő társaik $(\mathrm{p}=0,507)$.

A válás negatív hatása sem igazolódott be jelen mintán, hiszen a különbség az elvált és nem elvált szülők gyermekei közt nem szignifikáns $(\mathrm{p}=0,915)$, ahogyan a gyermekkori meseolvasás hatásának tekintetében is hasonló megállapítás tehető $(\mathrm{p}=0,798)$. Ehhez hasonlóan a jelenlegi munkavégzés tekintetében is az látható, hogy a dolgozó hallgatók tanulmányi eredményessége sem jelentősen marad el nem dolgozó hallgatótársaik eredményességétől $(\mathrm{p}=0,682)$.

Második modellünkben azonban már tapasztalhatóak szignifikáns hatások. Az első szembetűnő faktor az aktuális munkavégzés hatása, amely a pszichológiai faktorok bevonásával szignifikánssá válik $(\mathrm{p}=0,047)$. A személy önmagával való elégedettsége $(\mathrm{p}=0,022)$, a társas kirekesztés ténye $(\mathrm{p}=0,013)$, valamint a kirekesztéssel való megküzdés hatása $(p=0,04)$ volt emellett jelentős, így akik elégedettek magukkal, azok eredményesebbek, valamint a legalacsonyabb tanulmányi eredményességgel azok rendelkeznek, akiket már általános iskolában is érte kirekesztés, illetve akikben a sikeres megküzdés ellenére is mély nyomot hagyott a kirekesztés. A sportolás gyakoriság nem mutatott jelentős hatást $(\mathrm{p}=0,762)$, $\mathrm{s}$ bár a nem rendszeresen (napi vagy heti szinten) sportoló hallgatók eredményessége enyhén jobb, a Mann-Whitney próba eredményei alapján a sportoló és nem sportoló csoport közötti különbség tehát nem jelentős $(\mathrm{p}=0,795)$.

A lineáris regresszióanalízis eredményei alapján 
tehát negyedik hipotézisünk részben igazolódott, hiszen a kirekesztés maga negatív hatással bír a tanulmányi eredményességre, az énelégedettség, valamint a kirekesztéssel való megküzdés azonban pozitív hatást mutat. A rendszeres sporttevékenység pozitív hatása azonban jelen vizsgálatban nem igazolódott be.

\section{Megvitatás}

A tehetség, a sport, az elégedettség és a kirekesztéssel való megküzdés olyan tényezők, amelyek jelentős hatással lehetnek mindennapi életünkre. A sport az egészséges életmód részeként számos kedvező hatással bír, amely mind tanulmányi, mind nem-tanulmányi szempontokból kedvező hatásokat eredményezhet. A tehetség, akár objektív, akár szubjektív, komplex tényező, amely több területen, akár egyidejűleg is jelentkezhet, akár tanulással, akár múvészettel kapcsolatos területeken. A tehetséges személy egyrészt veszélyforrásnak lehet kitéve (hiszen kimagasló eredményességével kilóghat a közösségéből), másrészt a folyamatos önfejlesztés és a kihívások személyiségfejlődést eredményeznek. $\mathrm{Az}$ önmagunkkal kapcsolatos elégedettség olyan intraperszonális faktor, amely magára a személy intraperszonális és interperszonális sajátosságaira és eredményességére is hat, negatív megítélésként pedig negatív hatást fejt ki a személy életére, gondoljunk az önmagunkba vetett hitre, kitartásra, vagy éppen a szorongásra és megküzdésre (Csibi és Csibi, 2013). Utóbbi szerepe a személyiségfejlōdésben is mindenképp kiemelendő, hiszen mindennapjainkban folyamatosan találkozunk stresszforrásokkal, amelyekkel meg kell birkózni. A kirekesztés egy speciális terület, amely a szociális kapcsolathálóra épül, s ezen keresztül hat vissza az intraindividuális elemekre (Kovács, 2020; Kovács és Nagy, 2020).

Kutatásunkban ezeket a témaköröket jártuk körül egy egyetemista mintán. A kirekesztéssel kapcsolatos megküzdés a kitöltők többségében sikerrel zajló folyamat, amely azonban többnyire nyomot hagyott a személyek életében. A kutatás nem kérdezett rá a hatás irányára, azonban feltételezhetô, hogy a megküzdés sikere tényének ellenére a kirekesztéssel kapcsolatos gondolatok inkább negatív töltetúek, mintsem pozitívak. Fontos hangsúlyozni a kirekesztés esetében a fontos mások és a meglévő társas kapcsolatok szerepét. A kitöltők több, mint fele számolt be arról, hogy ebben az időszakban néhány osztálytársa támaszt nyújtott számára, ami logikus és ideális is, hiszen a sikeres életvitelnek és megküzdési rugalmasságnak nem a kapcsolatok száma, hanem a kapcsolatok minősége adhat stabil alapot (Ercsei és Nikitscher, 2012). Az érintettek 24\%-a nem kért segítséget a megküzdéshez (többségüknek nem volt szüksége egyéb segítségre a megküzdéshez), amely sikeres megküzdés esetén erōs személyiségre és stabil belső erőforrások meglétére vall. Pozitív, hogy akiknek segítségre volt szüksége, azok többsége élt a lehetőséggel, akár a család és kortársak, vagy éppen olyan segítő szakemberek vonatkozásában, mint a pszichológus vagy a pedagógus.

Megvizsgáltuk a tehetség és a megküzdés közötti összefüggést. Az eredmények alapján megállapítható, hogy nincs különbség a tehetséges és nem tehetséges tanulók között a kirekesztés tényében, és a kirekesztéssel való megküzdésben sem. Ebben szerepet játszhat az a tény, hogy egyetemi hallgatókat kérdeztünk meg, akik az egykori középiskolásoknak egy kiválogatott csoportját jelentik, ezáltal valószínúsíthetően eleve sikeres megküzdés van mögöttük (Nuñez-Fadda és tsai, 2020). Felsőoktatásba való bejutásukkal bizonyították a korábbi életszakaszok nehézségeinek leküzdését például a tanulmányok, a karriertudatosság területén (Ceglédi, 2018).

Feltételeztük továbbá, hogy a sportoló személyekre kevésbé jellemző a kirekesztés, eredményeink azonban nem igazolták ezt a feltételezést. A sport ugyanúgy “megkülönböztető jelzés"-ként szolgálhat, mint az egyéb, a szakirodalomban már 
bemutatott tényezők. A sportoló személyekre - különösen a rendszeresen és magasabb szinteken sportolókra - sajátos értékek és viselkedéskultúra jellemző, amit kompenzálhat és stabilizálhat a társas kompetenciájuk, és az így kialakult kapcsolati hálójuk (Kovács és Nagy, 2016). Ez azonban önmagában még nem garantálja a sikeresebb megküzdést ezen a szinten (sokkal inkább a későbbi életkorban).

A sport és elégedettség közötti kapcsolatra alapozva megvizsgáltuk, hogy a tehetséges, valamint a sportoló hallgatók esetében egy magasabb elégedettségi ráta mutatható ki. Azonban az eredmények tükrében ez nem látszik beigazolódni, hiszen bár mind a sportoló, mind a tehetséges személyek közt valóban magasabb azoknak az aránya, akik elégedettek önmagukkal, a különbség nem szignifikáns. Az önmagunkkal való elégedettség egy komplex tényező, amelyet az olyan egyéni faktorok mellett, mint a sportolás vagy tehetség, számos egyéb tényező is meghatároz, akár a személyen belüli individuális, akár a kontextuális, interperszonális faktorok (Ceglédi, 2018; Kovács, 2020). Ezek képesek lehetnek felülírni az egyébként elvárt sportolói és tehetségidentitás hatásait, így ennek vizsgálata mélyebb feltárást igényel.

Végül a tanulmányi eredményességre ható faktorok vizsgálatára került sor. A kirekesztés negativ hatással bír a tanulmányi eredményességre, hiszen a kirekesztés által okozott negatív következmények magára a személyiségre is negatívan hatnak, legalábbis átmenetileg, amíg a megküzdési folyamat tart és sikeressé válik. A sikeres megküzdés azonban akár pozitívvá is válhat a rövidtávú negatív hatást követően, hiszen ezáltal a személy erősebbé válik, személyisége komplexebb lesz, és megtanulja kezelni a hasonló szituációkat és az azokkal érkező negatív ingereket, érzéseket. A vártnak megfelelóen az énelégedettség, valamint a kirekesztéssel való megküzdés pozitív hatást mutat a tanulmányok vonatkozásában. Utóbbi hátterében az előbbiekben ismertetett háttér állhat, előbbi pozitív hatását pedig már korábbi kutatások is igazolták (Kovács, 2018; Kovács és Nagy, 2017b). A rendszeres sporttevékenység pozitív hatása azonban jelen vizsgálatban nem igazolódott be. Ez az eredmény követi a hazai és nemzetközi kutatások ambivalens eredményeinek vonalát: a sportolás tanulmányokra kifejtett hatásáról megoszlik a kutatók véleménye, hiszen egyes tanulmányok pozitív, mások negatív hatásra hívják fel a figyelmet, egy harmadik irányzat pedig a kettő közötti kapcsolat hiányát nevezi meg.

\section{Korlátozások}

A kutatás egyik korlátja a mintanagyság. A biztosabb eredmények érdekében a jövőben érdemes a kérdésköröket nagyobb mintán is vizsgálni, törekedve a reprezentativitás elvének követésére. A kutatás eredményei reprezentativitás hiányában nem generalizálhatóak a teljes egyetemi populációra. Továbbá jelen kutatásban egyéni, többnyire zárt kérdések megfogalmazására került sor, sztenderdizált kérdőívek alkalmazása nem volt jelen. További összefüggések feltárásához érdemes lesz a fent megfogalmazott kérdéseket és megállapításokat validált és sztenderdizált kérdőívekkel és kérdésblokkokkal kiegészíteni.

\section{Konklúziók}

A megküzdés fontosságának kapcsán a kirekesztés-coping egy speciális területre mutat rá, s hangsúlyozandó a korai tapasztalatok és az alkalmazott coping stratégiák szerepe is, amely további kutatások alapját képezi. Mivel ezek az emlékek és tapasztaltok a későbbi életszakaszokban is jelentős hatást fejthetnek ki (még sikeres megküzdés esetén is), a prevenció és intervenció kérdéskörét szükséges kiemelni, ezek gyakorlati alkalmazását fenntartani és növelni a kirekesztést és a bántalmazás egyéb eseteit tekintve. A megküzdés a tehetség kibontakozásában és perzisztenciájában is megtalálható, ugyanakkor jelen kutatásban ez kevésbé domborodott ki, ahogyan a sport protektív 
szerepe sem látszott - vélhetően a minta sajátosságaiból fakadóan. A tanulmányi eredményesség vonatkozásában a kirekesztéssel való megküzdés, a poszttraumatikus növekedés analógiájára, hosszú távon a személyiség formálódásával pozitív hatás jelentkezhet, ahogyan eredményeink is mutatják. Ehhez hasonlóan az én-elégedettség érzése is pozitív hatást fejt ki, így a pozitív önértékelés kialakítása kiemelten hangsúlyos, akár a kortárskapcsolatok, akár a családon belüli és a tanár-diák kapcsolatok vonatkozásában mint a társas támasz lehetséges színterei.

Eredményeink felhívják a figyelmet a szociális kapcsolatok és a kirekesztés elleni prevenció fontosságára, hiszen a társas kirekesztés hosszútávon az önértékelésre és a felsőfokú tanulmányi eredményességre is kihathat, és annál erősebb, minél korábbi színtéren jelenik meg. A támogató közegben végbemenő sikeres megküzdés ugyanakkor életre szóló tanulságokkal szolgálhat.

\section{Irodalom}

Adelson, J. L. (2007). A „Perfect” Case Study: Perfectionalism in Academically Talented Fourth Graders. Gifted Child Today, 30(4), 14-20.

Bacskai K. (2020). Az iskola és a család kapcsolata. Kapocs, 19(2), 11-20.

Bagdy E., Kövi Zs. \& Mirnics Zs. (2014). Fény és árnyék: A tehetségerök felszabaditása. Budapest: Magyar Tehetségsegító Szervezetek Szövetsége.

Ceglédi T. (2008). Hátrányos helyzetû tehetségek a Debreceni Egyetemen. Educatio, 17(4), 597-604.

Ceglédi T. (2012). Reziliens életutak, avagy a hátrányok ellenére sikeresen kibontakozó iskolai karrier. Szociológiai Szemle, 22(2), 85-110.

Ceglédi T. (2018). Ugródesžkán. Reziliencia és társadalmi egyenlótlenségek a felsöoktatásban. Debrecen: CHERD-Hungary.

Ceglédi T. (2020). Mitôl lendül az ugródeszka? A hátrányok ellenére sikeres, reziliens negyedikes diákokat segítő tényezők. Kapocs, 19(2), 65-80.
Ceglédi T., Nyüsti Sz. (2011). „A jók mennek el?” Szelektív elvándorlás Hajdú-Bihar megye felvételizői körében. Felsóoktatási Múbely, 2(4), 95117.

Coleman, J. S. (1996). Iskolai teljesítmény és versenystruktúra. In Cs. Meleg (Ed.), Iskola és társadalom I. Pécs: JPTE. 120-130.

Csányi T. (2010). A fiatalok fizikai aktivitásának és inaktív tevékenységének jellemzői. Új pedagógiai szemle, 60(3-4), 115-128.

Csibi S., Csibi M. (2013). Az önértékelés és a megkeüzdés szerepe a serdïlók egészségvédó magatartásában. Kolozsvár-Nagyvárad: Babes-Bolyai Tudományegyetem-Partiumi Keresztény Egyetem.

Dávid I., Fülöp M., Pataky N., Rudas J. (Eds.) (2014a). Stressz, megküzdés, versengés, konflik-tusok. Budapest: Magyar Tehetségsegítő Szer-vezetek Szövetsége.

Dávid M., Gefferth É., Nagy T., Tamás M. (Eds.) (2014b). Mentorálás a tehetséggondozásban. Budapest: Magyar Tehetségsegító Szervezetek SzÖvetsége.

Dukay-Szabó Sz., Túry F. (2008). Testkép- és evészavarok látássérültek körében. Mentálhigiéné és Pszichoszomatika, 9(2), 139-147

Ercsei, K., Nikitscher, P. (2012). Tanulók közötti konfliktusok típusai. Új Pedagógiai Sžemle, 7$8(62), 42-54$.

European Commission (2018). Special Eurobarometer 472: Sport and physical activity. European Union. Letöltés: 2020. 12. 20. https://data.europa.eu/euodp/en/data Ldataset/S2164_88_4_472_ENG

Evans, J., Rich, E., Holroyd, R. (2004). Disordered eating and disordered schooling. What schools do to middle class girls. British Journal of Sociology of Education, 25(2), 123-142. doi: $10.1080 / 0142569042000205154$

Fehér Á. (2009). Az empátia lehetőségei a kirekesztődés. In Kállai E., Kovács L. (Eds.), 
Megismerés és elfogadás (pp. 132-143). Budapest: Nyitott Könyvmúhely Kiadó KFT.

Fekete I. (2019). A tehetség: átok vagy áldás? Új Köznevelés, 5-6, 42.

Fülöp M. (2014). A versengéssel, a győzelemmel és a vesztéssel való adaptív megküzdés tehetséges diákoknál. In Dávid I. (Ed.), Stressz, megküzdés, versengés, konfliktusok. Budapest: MATEHETSZ. 123-205.

Godó, K., Ceglédi, T., Kiss, A. (2020). The Mentoring's Role among Alumni Students of István Wáli Roma College for Advanced Studies of the Reformed Church. Central European Journal of Educational Research, 2(1), 36-52. doi. 10.37441/CEJER/2020/2/1/5757

Groves, K. S. (2011). Talent management best practices: How exemplary health care organizations create value in a down economy. Health Care Management Review, 36(3), 227-240. doi. 10.1097 / HMR.0b013e3182100ca8

Hadházy, J. (2016). Tanulói konfliktusformák feltárása és kezelése egy általános iskola felsô tagozatán. Opus et Educatio, 3(2), 3-17.

Hafičová, H.; Dubayová, T.; Kovács, E.; Ceglédi, T.; Kaleja, M. (2020). Mentor and Social Support as Factors of Resilience and School Success: Analyses of Life Narratives of University Students from Marginalized Roma Communities. Varsó, Lengyelország: Ośrodek WydawniczoPoligraficzny „SIM” Hanna Bicz.

Harmatiné-Olajos T., Pataky N. (2014). A lelki egészség személyiségdinamikai Kettősségei kihívások a tehetséggondozásban. Budapest: MATEHESZ.

Harmatiné Olajos T., Pataky N., K. Nagy E. (2014). A kétszeresen kivételes tanulók tehetséggondozása. Budapest: MATHETSZ.

Kovács K. (2015). A sportolási szokások és a tanulmányi eredményesség egy határmenti régió hallgatóinak körében. Educatio, 24(2), 130-138.

Kovács K. E. (2018). The characteristics and territorial distribution of health-behavioural clusters among students. In G. Keresztes, Cs. Szabó (Eds.), Tavaszi Szél $2018=$ Spring Wind 2018. Budapest: Doktoranduszok Országos Szövetsége (DOSZ). 336-348.

Kovács K. E. (2020). Egésaség és tanulás a köznevelési tipusú sportiskolákban. Debrecen: CHERDHungary.

Kovács K. E., Nagy B. E. (2015). A sportolás hatása kiskamaszok énképére, szorongására és megküzdésére. Különleges Bánásmód, 1(3), 43-56.

Kovács K. E., Nagy B. E. (2016). Tehetséggondozás a sportban mint az inklúzív nevelés egyik színtere. In Semsei I., Kovács K.(Eds.), Inkluziviv nevelés - inkluzív társadalom Debrecen: Debreceni Egyetemi Kiadó. 268-293.

Kovács K. E., Nagy B. E. (2017a). Adolescents' health behaviour according to sport and family structure. Különleges Bánásmód, 3(1), 27-37.

Kovács K. E., Nagy B. E. (2017b). Egészségtudatos magatartás alakulása a sport függvényében. Educatio, 26(4), 649-656.

Kovács K. E., Nagy K. R. (2020). Egészséggel kapcsolatos attitűdök, szorongás és megküzdés a Debreceni Egyetem tanár szakos hallgatói körében. (kézirat).

Lajos A. (2005). Az egészségtudatosság sajátos vonásai a 14-18 éves korosztályban, különös tekintettel az élelmiszerfogyasżásra. Gödölló: Szent István Egyetem.

Ludányi B., Szabó P. (2017). Evészavarok és az iskola: kockázati tényező vagy a megelőzés terepe? Magyar Pedagógia, 117, 73-93.

Mező F. (Ed.) (2008). Tehetségdiagnosztikea. Nitra \& Debrecen: Kocka Kör.

Neuwirth G., Szemerszki M. (2009). Tehetséggondozás a középiskolában, tehetségek a felsôoktatásban. Educatio, 17(2), 204- 219.

Nuñez-Fadda, S. M., Castro-Castañeda, R., VargasJiménez, E., Musitu-Ochoa G., \& CallejasJerónimo, J. E. (2020). Bullying Victimization among Mexican Adolescents: Psychosocial Differences from an Ecological 
Approach. International Journal of Environmental Research and Public Health, 17(13), 4831.

Oláh A. (2005). Érzelmeke, megkeüzdés és optimális élmény. Budapest: Trefort Kiadó.

Rongen, F., McKenna, J., Cobley, S., \& Till, K. (2018). Are youth sport talent identification and development systems necessary and healthy? Sports Medicine - Open 4, 18.

Sinkó I. (2009). A gondozott és gondozatlan tehetségek. Új Pedagógiai Szemle, 5-6, 112-118.
Szemerszki M. (Ed., 2015). Eredményesség az oktatásban. Dimenziók és megközzlitések Buda-pest: Oktatásfejlesztő és Kutató Intézet.

Szumska I. (2004). Evészavarok prevalenciaja fiatal magyar nök körében- Pszichoszociális háttérjel-lemqő"k, komorbiditás más mentális problémákekal. Budapest: Semmelweis Egyetem.

Túry F. (2002). Anorexia és bulimia: az evés zavarai a mindennapos gyakorlat szemszögéből. Hippocrates, 4(2), 110-114. 